\title{
High Uranium Concentrations in the Groundwater of the Rio de Janeiro State, Brazil, Mountainous Region
}

\author{
José M. Godoy, ${ }^{\circ *, a}$ Paulo R. Ferreira, ${ }^{b}$ Elder M. de Souza, ${ }^{b}$ Larisse I. da Silva, ${ }^{a}$ \\ Isabela C. S. Bittencourt ${ }^{\circledR a}$ and Felipe Fraifeld ${ }^{c}$ \\ ${ }^{a}$ Departamento de Química, Pontifícia Universidade Católica do Rio de Janeiro, \\ 22453-900 Rio de Janeiro-RJ, Brazil \\ ${ }^{b}$ Instituto de Radioproteção e Dosimetria, Comissão Nacional de Energia Nuclear, \\ Av. Salvador Allende s/n, Recreio dos Bandeirantes, 22783-127 Rio de Janeiro-RJ, Brazil \\ 'Departamento de Engenharia Civil e Ambiental, \\ Pontifícia Universidade Católica do Rio de Janeiro, 22453-900 Rio de Janeiro-RJ, Brazil
}

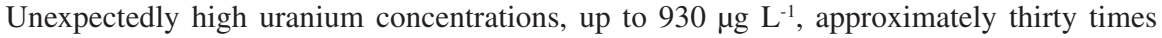
higher than the World Health Organization (WHO) guidance level, were observed in groundwater samples from the mountainous region near Rio de Janeiro City, the so-called "Região Serrana", approximately $60 \mathrm{~km}$ from the city. This region is characterized by a large number of tourist activities and water-related industries, such as mineral water and breweries that can be impacted by these findings. In addition, the water supplies in small communities of this region are partially or entirely based on groundwater sources. Uranium contamination was observed in 7 of the 16 counties in this region. Based on these data, this study concluded that the probability of obtaining uraniumcontaminated groundwater is high in some specific areas of this region. In addition, high ${ }^{222} \mathrm{Rn}$ concentrations were verified, with levels reaching $1570 \mathrm{~Bq} \mathrm{~L}^{-1}$. Furthermore, a maximum level of $4.6 \mathrm{~Bq} \mathrm{~L}^{-1}{ }^{210} \mathrm{~Pb}$ was also measured, which has a WHO guidance level of $0.1 \mathrm{~Bq} \mathrm{~L}^{-1}$. Based on the present findings, it is suggested that any artesian well deeper than $80 \mathrm{~m}$ in this region should be tested for uranium and ${ }^{222} \mathrm{Rn}$.
\end{abstract}

Keywords: groundwater, Rio de Janeiro, radon, uranium, natural radioactivity

\section{Introduction}

The mountainous region near Rio de Janeiro City is known for its mild climate and has been used as a summer residence for those living in Rio de Janeiro since the Brazilian imperial time, with the construction of the Pedro I summer residence in 1847. The region has 16 municipalities. The main city in this region, with 300,000 inhabitants, was named Petrópolis in honor of Pedro I, the first Brazilian emperor, and is only $65 \mathrm{~km}$ from Rio de Janeiro City. The second largest city is named Teresópolis, which refers to Teresa, Pedro's wife. Its economy has a strong tourism component because it is considered a healthy climate region with high-quality mineral water. In addition, it has well-known breweries and many hotels and guesthouses.

*e-mail: jmgodoy@puc-rio.br
Godoy and Godoy ${ }^{1}$ investigated the natural radioactivity in Brazilian groundwater; 210 samples were analyzed for uranium, and the highest value observed was $7.5 \mu \mathrm{g} \mathrm{L} \mathrm{L}^{-1}$. Full chemical and physical-chemical analyses were also performed, and no statistically valid correlation was observed between the uranium concentration and the additional parameters. ${ }^{1}$ Banks et al. ${ }^{2}$ presented the results related to a survey of inorganic chemical parameters in European tap water samples involving approximately 580 samples; the highest observed uranium concentration was $56 \mu \mathrm{g} \mathrm{L}{ }^{-1}$, and no clear correlation was verified between uranium and any other parameter. Dinelli et al. ${ }^{3}$ compared the chemical compositions of tap and bottled water in Italy, including the uranium concentrations, which had a similar distribution for both water types, with a maximum of $18 \mu \mathrm{g} \mathrm{L}^{-1}$ in tap water and $31 \mu \mathrm{g} \mathrm{L}^{-1}$ in bottled water. Yang et al. ${ }^{4}$ studied uranium and radon in groundwater samples from Maine during a study that involved 
5857 samples; they concluded that elevated concentrations were observed within or close to granitic intrusions, and uranium concentrations up to $3500 \mu \mathrm{g} \mathrm{L}^{-1}$ were obtained. As a conclusion of their work, Yang et al. ${ }^{4}$ suggested that uranium testing was necessary within a distance of $5-10 \mathrm{~km}$ from a mapped granitic boundary.

Despite its high pluviometric level of 1600-2200 mm, the mountainous region has an uneven rainfall distribution with long annual periods at a very low precipitation index that may even reach zero, which led to the establishment of an emergency plan, due to the water shortage, by the local authorities. ${ }^{5}$ To avoid water scarcity, according to the local drilling companies, this region lives an increment on the number of new artesian wells drilled yearly. The local geology is dominated by granitic rocks with frequent quartz and carbonate intrusions, which also contain embedded monazite, zirconite and apatite grains. ${ }^{6}$ After drilling a new well, some of these local companies customarily send a well water sample to Pontifical Catholic University of Rio de Janeiro (PUC-Rio), Water Characterization Laboratory (LABAGUAS), to evaluate the water quality.

The present work aims to publicize the very high uranium concentrations, up to $930 \mu \mathrm{g} \mathrm{L}^{-1}$, that were observed in some groundwater samples originating from this region in the hope that the evaluation of the natural radioactivity in these waters will become mandatory before the water is released for human consumption. It intents, also, to define the sub-region, within Rio de Janeiro State mountainous region, where the probability to observe uranium concentration, above than the Brazilian regulatory limits, ${ }^{7}$ is higher than the others.

\section{Experimental}

The present study includes only groundwater samples originated from the Rio de Janeiro state mountainous region, sent to PUC-Rio by drilling companies and which have presented uranium concentration higher than the
Brazilian regulation. ${ }^{7}$ Table 1 contains the coordinates (UTM) of each location where a uranium concentration higher than the Brazilian regulatory limits were observed, the number of wells and the depth.

Although these drilling companies have a long market tradition, for the sampling, they are instructed to use only new polyethylene bottles and wash it, at least three times with the sample, before filling it to the top. It is also recommended to maintain the samples in the refrigerator and to deliver them as soon as possible. The samples were collected directly from each well after keeping the water flowing for several minutes in order to stabilize the chemical composition. Electrical conductivity was also monitored when possible.

At PUC-Rio's Water Characterization Laboratory (LABAGUAS), a full chemical characterization was performed, including physical-chemical assays and the determination of major cations and anions by ion-chromatography, trace elements by inductively coupled plasma-mass spectrometry (ICP-MS) and, when requested, ${ }^{222} \mathrm{Rn}$ by liquid scintillation counting ${ }^{8}$ and ${ }^{228} \mathrm{Ra},{ }^{226} \mathrm{Ra}$, and ${ }^{210} \mathrm{~Pb}$ by radiochemical separation. ${ }^{9}$ The physical-chemical parameters were determined using non-filtered samples while all other parameters were determined after filtration applying $0.45 \mu \mathrm{m}$ membrane filters. Table 2 presents all the assays performed and the related methodology.

In sites 1, 2 and 8 a visit was allowed and an in situ sampling was carried out, which included ${ }^{222} \mathrm{Rn}$ sampling and further determination of ${ }^{228} \mathrm{Ra},{ }^{226} \mathrm{Ra}$ and ${ }^{210} \mathrm{~Pb}$. Related to site 8 , in special, ${ }^{228} \mathrm{Ra}$ and ${ }^{226} \mathrm{Ra}$ were included once these parameters are included on the Brazilian regulation for public water supply. ${ }^{7}$ At site 2 an external dose survey was carried out using a portable spectral gamma radiation scanning spectrometer (AT6101C model, ATOMTEX), coupled with a GPS device and comprising a $\mathrm{NaI}(\mathrm{Tl})$ scintillator with a 512-channel spectrum band for detecting gamma energy and dose rate ranges of 40 to $3,000 \mathrm{keV}$ and 0.01 to $100 \mu \mathrm{Sv} \mathrm{h}^{-1}$, respectively. ${ }^{18}$

Table 1. Geographical coordinates, counties, number of wells studied and depth according to the studied sites

\begin{tabular}{lccccc}
\hline Site & Coordinate X & Coordinate Y & County & Number of wells & Depth / m \\
\hline 1 & -22.58273 & -43.16745 & Magé & 6 & $80-120$ \\
2 & -22.42439 & -43.11896 & Petrópolis & 1 & 250 \\
3 & -22.46164 & -43.14567 & Petrópolis & 1 & 78 \\
4 & -22.27148 & -42.92751 & Teresópolis & 2 & 85 \\
5 & -21.99536 & -42.9146 & Sapucaia & 1 & 80 \\
6 & -22.18734 & -43.27576 & Paraíba do Sul & 1 & 80 \\
7 & -22.1118 & -43.11171 & Três Rios & 17 & $80-120$ \\
8 & -22.1491 & -42.91353 & São José do Vale do Rio Preto (SJVRP) & \\
\hline
\end{tabular}


Table 2. Applied methodology according with the assay carried out in the studied groundwater samples

\begin{tabular}{|c|c|c|}
\hline Assay & Methodology & Reference method \\
\hline$\overline{\text { Color }}$ & spectrophotometry & NBR-13798-9710 \\
\hline Turbidity & nephelometry & NBR-11265-90 \\
\hline $\mathrm{pH}$ & potenciometry & ASTM-D1293-18 \\
\hline Conductivity & conductimetry & ASTM-D1125-14 ${ }^{13}$ \\
\hline Total dissolved solids & calculated & \\
\hline Hardness & calculated & \\
\hline Total alkalinity & titration & ASTM-D1067-16 \\
\hline Carbonate & titration & ASTM-D1067-16 ${ }^{14}$ \\
\hline Bicarbonate & titration & ASTM-D1067-16 ${ }^{14}$ \\
\hline $\begin{array}{l}\text { Fluoride, chloride, } \\
\text { bromide, nitrate, } \\
\text { phosphate and sulfate }\end{array}$ & ion-chromatography & ASTM-D4327-17 \\
\hline $\begin{array}{l}\text { Sodium, potassium, } \\
\text { calcium and } \\
\text { magnesium }\end{array}$ & ion-chromatography & ASTM D6919-17 \\
\hline Trace elements & ICP-MS & EPA $200-8^{17}$ \\
\hline
\end{tabular}

ICP-MS: inductively coupled plasma-mass spectrometry.

Indoor radon measurements were performed using a RAD7 Radon Detector (Durridge Company Inc.) operating in the normal counting mode at ten-minute cycle times.

\section{Results and Discussion}

With the establishment of the new Brazilian regulation on drinking water quality ${ }^{7}$ in December 2011, uranium determination started to be routinely conducted for any groundwater sample received in PUC-Rio's Water Characterization Laboratory (LABAGUAS), and since then, approximately 100 groundwater samples from the mountainous region around Rio de Janeiro City have been analyzed. Uranium is considered a naturally occurring chemical that has health concerns in drinking water, ${ }^{19}$ and the World Health Organization (WHO) recommended limit was revised from $15 \mu \mathrm{g} \mathrm{L}^{-1}$ in the $3^{\text {rd }}$ edition (2003) to $30 \mu \mathrm{g} \mathrm{L}^{-1}$ in the $4^{\text {th }}$ edition (2017). ${ }^{19} \mathrm{In}$ the Brazilian regulatory system, both values are present: $15 \mu \mathrm{g} \mathrm{L}^{-1}$ is adopted by the Brazilian Environmental Council (CONAMA) for water management purposes (CONAMA 396/2008), and $30 \mu \mathrm{g} \mathrm{L}^{-1}$ is the regulatory limit for the public water supply system (Health Department, MS 2914/2011).?

Since one of the objectives of the present work is to define the region where the probability to observe uranium concentration above the Brazilian regulatory limits ${ }^{7}$ is higher than the others, it was decided to present the obtained results by sites, where each site represents a situation, which can be a house or a mineral water plant, where high uranium concentration was observed. The number of wells in each of these sites ranged from only one (e.g., site 2) up to seventeen (site 8). Table 3 contains the uranium results of 30 wells considered in the present work, as well as, ${ }^{222} \mathrm{Rn}$, ${ }^{228} \mathrm{Ra},{ }^{226} \mathrm{Ra}$ and ${ }^{210} \mathrm{~Pb}$ when available.

Site 1 is a mineral water plant, which is one of the main mineral water producers in Rio de Janeiro. It is located in Magé County. At this site, there are six artesian wells: three wells are in the front part of the facility, and three are at the back of the facility. The wells in the front part had a higher conductivity $\left(180-230 \mu \mathrm{S} \mathrm{cm}^{-1}\right)$ than those at the end (90-120 $\left.\mu \mathrm{S} \mathrm{cm}^{-1}\right)$, and they presented uranium concentrations up to $62 \mu \mathrm{g} \mathrm{L}^{-1}$; in contrast, the other three wells presented uranium concentrations between 1 and $5 \mu \mathrm{g} \mathrm{L}{ }^{-1}$. The Durov diagram (Figure 1) shows two groups of water sources, one with a lower conductivity corresponding to the wells with lower uranium content and another with a higher conductivity, representing the wells with higher uranium content. However, only one well (AMM-3) presented geochemical facies different from those of the other five, showing a mixture of calcium bicarbonate with sodium chloride facies. The sodium chloride facies can be an influence of the seawater spray because this site is located only $14 \mathrm{~km}$ from the shoreline, which has no impact on the uranium content, as this well presented a uranium concentration lower than $1 \mu \mathrm{g} \mathrm{L}{ }^{-1}$.

Because site 1 represents a bottled mineral water industry, bottled waters were purchased in supermarkets in order to evaluate potential contamination to the public by consuming it. The bottled waters sold were a blend of the low- and high-conductivity waters, as shown in Figure 2, with uranium content mostly below $30 \mu \mathrm{g} \mathrm{L}^{-1}$. It must be pointed out that this procedure of blending water from different wells is not allowed by the Brazilian regulation because the chemical composition on the label represents one specific well and not a mixture. Since it was dealing with a bottled mineral water, it was decided to investigate also other WHO recommend radionuclides as ${ }^{210} \mathrm{~Pb},{ }^{226} \mathrm{Ra}$ and ${ }^{228} \mathrm{Ra}^{19}$ The observed median values of ${ }^{226} \mathrm{Ra}$ and ${ }^{210} \mathrm{~Pb}$ in the bottled water were 0.018 and $0.24 \mathrm{~Bq} \mathrm{~L}^{-1}$, respectively, and ${ }^{228} \mathrm{Ra}$ was below the detection limit $(0.050 \mathrm{~Bq} \mathrm{~L}-1)$ in all analyzed samples. The ${ }^{226} \mathrm{Ra}$ and ${ }^{210} \mathrm{~Pb}$ WHO guidance levels are 1.0 and $0.1 \mathrm{~Bq} \mathrm{~L}^{-1}$, respectively, that means the bottled waters from this label exceed the ${ }^{210} \mathrm{~Pb}$ guidance level.

Site 2 occurred at a summerhouse in the Nogueira District of Petrópolis County. Representing the deepest well analyzed in this study $(250 \mathrm{~m})$, its first sample was sent to PUC-Rio's laboratory after the well had just been drilled, and the observed uranium concentration of $930 \mu \mathrm{g} \mathrm{L}^{-1}$ was the highest found during the present work. To rule out 
Table 3. Uranium, ${ }^{222} \mathrm{Rn},{ }^{226} \mathrm{Ra}$ and ${ }^{210} \mathrm{~Pb}$ concentrations in the groundwater samples (uranium values in bold are the ones higher than $30 \mu \mathrm{g} \mathrm{L}{ }^{-1}$, established by MS 2914/2011 and WHO) $)^{7,19}$

\begin{tabular}{|c|c|c|c|c|}
\hline Sample code & $\mathrm{U} /\left(\mu \mathrm{g} \mathrm{L}^{-1}\right)$ & ${ }^{222} \mathrm{Rn} /\left(\mathrm{Bq} \mathrm{L}^{-1}\right)$ & ${ }^{210} \mathrm{~Pb} /(\mathrm{Bq} \mathrm{L}-1)$ & ${ }^{226} \mathrm{Ra} /\left(\mathrm{Bq} \mathrm{L}{ }^{-1}\right)$ \\
\hline AMM-1 & 60 & $75 \pm 8$ & $0.53 \pm 0.11$ & ND \\
\hline AMM-2 & 1.5 & $109 \pm 7$ & $0.211 \pm 0.054$ & ND \\
\hline AMM-3 & 1.2 & $59 \pm 6$ & $0.240 \pm 0.056$ & ND \\
\hline AMM-4 & 5.2 & $90 \pm 6$ & $0.248 \pm 0.047$ & ND \\
\hline AMM-5 & 62 & $117 \pm 7$ & $0.239 \pm 0.048$ & ND \\
\hline AMM-6 & 34 & ND & ND & ND \\
\hline Site 2 & 640 & $790 \pm 23$ & $4.60 \pm 0.29$ & $0.654 \pm 0.072$ \\
\hline Site 3 & 15 & ND & ND & ND \\
\hline Site 4 & 270 & ND & ND & ND \\
\hline Site 5-1 & 52 & ND & ND & ND \\
\hline Site $5-2$ & 390 & ND & ND & ND \\
\hline Site 6 & 15 & ND & ND & ND \\
\hline Site 7 & 15 & ND & ND & ND \\
\hline SJVRP-1 & 36 & ND & $0.283 \pm 0.028$ & $0.318 \pm 0.034$ \\
\hline SJVRP-2 & 36 & $369 \pm 16$ & $0.429 \pm 0.033$ & $<0.050$ \\
\hline SJVRP-3 & $<1$ & ND & $0.745 \pm 0.048$ & $0.061 \pm 0.006$ \\
\hline SJVRP-4 & 2 & $181 \pm 11$ & $0.189 \pm 0.024$ & $<0.050$ \\
\hline SJVRP-5 & 1 & ND & $0.135 \pm 0.024$ & $0.082 \pm 0.009$ \\
\hline SJVRP-6 & 29 & $341 \pm 15$ & $0.261 \pm 0.032$ & $0.063 \pm 0.007$ \\
\hline SJVRP-7 & 185 & $1569 \pm 33$ & $0.818 \pm 0.052$ & $0.215 \pm 0.023$ \\
\hline SJVRP-8 & 5 & ND & $0.158 \pm 0.026$ & $0.148 \pm 0.016$ \\
\hline SJVRP-9 & 40 & $252 \pm 13$ & $0.139 \pm 0.024$ & $0.072 \pm 0.008$ \\
\hline SJVRP-10 & 120 & ND & $0.336 \pm 0.031$ & $<0.050$ \\
\hline SJVRP-11 & 68 & $226 \pm 12$ & $0.347 \pm 0.038$ & $0.078 \pm 0.008$ \\
\hline SJVRP-12 & 1 & ND & $0.392 \pm 0.036$ & $<0.050$ \\
\hline SJVRP-13 & 3 & $766 \pm 23$ & $0.348 \pm 0.046$ & $0.106 \pm 0.011$ \\
\hline SJVRP-14 & 1 & ND & $0.199 \pm 0.033$ & $<0.050$ \\
\hline SJVRP-15 & 2 & $491 \pm 19$ & $0.272 \pm 0.031$ & $<0.050$ \\
\hline SJVRP-16 & 20 & ND & $0.206 \pm 0.030$ & $<0.050$ \\
\hline SJVRP-17 & 1 & $62.6 \pm 6.7$ & $0.177 \pm 0.069$ & $<0.050$ \\
\hline
\end{tabular}

ND: not determined.

\section{Durov Diagram}

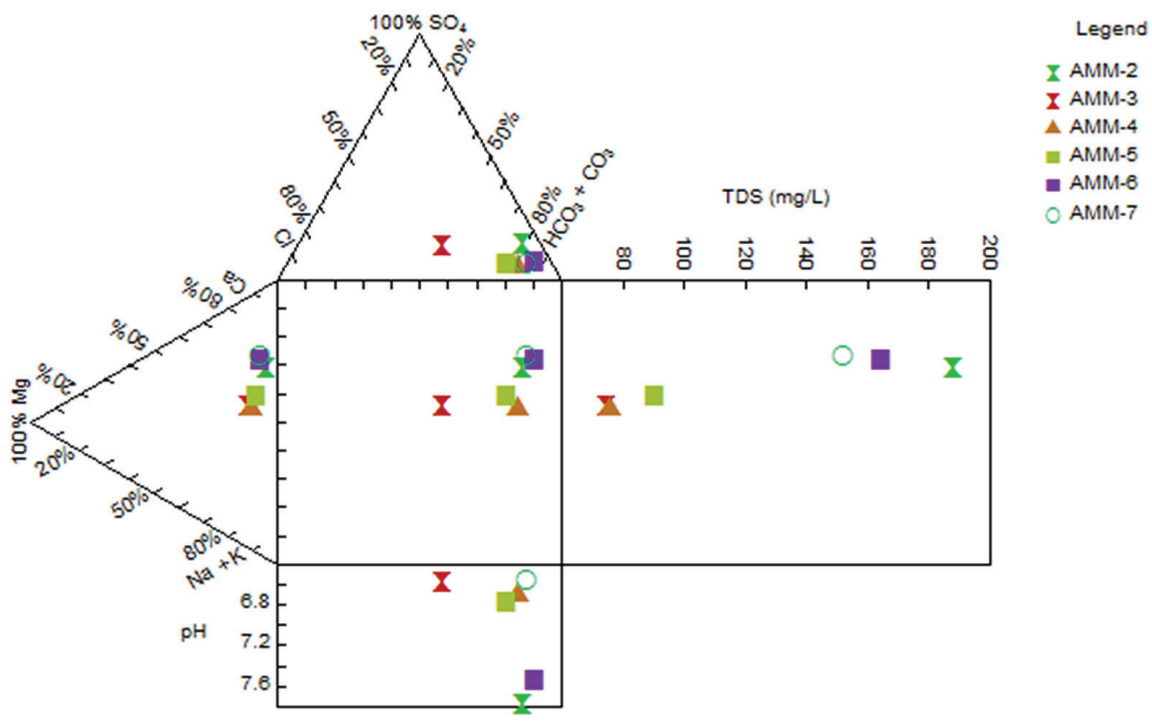

Figure 1. Durov diagram of the samples from site 1. 


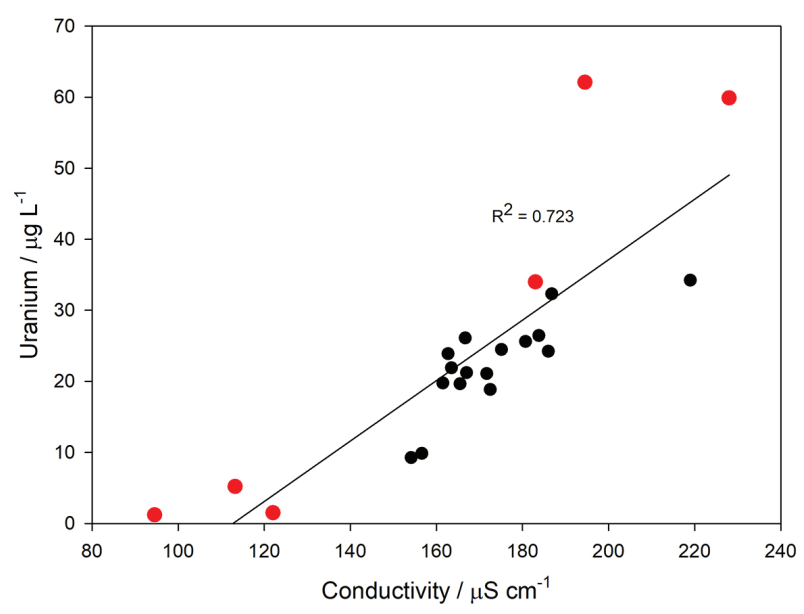

Figure 2. Uranium and conductivity relationship for the bottled mineral water samples (O) and the well samples (O) from site 1. The determination coefficient includes bottled water and well samples.

any hypothesis of possible contamination of the well that might have occurred during the drilling process, the drilling company performed the second sampling after one month of continuous pumping, and the uranium concentration decreased to $430 \mu \mathrm{g} \mathrm{\textrm {L } ^ { - 1 }}$, which is still approximately twelve times higher than the WHO limit. ${ }^{19}$ Due to this finding, a more intensive sampling campaign was carried out involving not only the water uranium analysis, but also a radiometric survey of the region; a radon measurement was performed in the house, the dissolved radon in the water and ${ }^{210} \mathrm{~Pb},{ }^{226} \mathrm{Ra}$ and ${ }^{228} \mathrm{Ra}$ were determined. Only one external gamma dose rate hot spot $\left(0.50 \mu \mathrm{Sv} \mathrm{h}^{-1}\right)$ was observed and represented the wellhead (Figure 3), where radon emanation was detected with the portable spectral gamma radiation spectrometer, which means that the rock containing the uranium is verified to be very deep and is not detectable at the surface. Once the uranium-containing rock is not observed at the surface, high radon emanation from the soil is not expected; consequently, the indoor radon levels of $10-30 \mathrm{~Bq} \mathrm{~m}^{-3}$ were within the range observed by Magalhães et $a l .{ }^{20}$ for indoor radon in Rio de Janeiro State. The collected water had a uranium concentration of $640 \mu \mathrm{g} \mathrm{L}^{-1}$, which is between the two previous results (930 and $430 \mu \mathrm{g} \mathrm{L} \mathrm{L}^{-1}$ ). The observed dissolved ${ }^{222} \mathrm{Rn}$ concentration was $790 \mathrm{~Bq} \mathrm{~L}^{-1}$, and consequently, the obtained concentration of $4.6 \mathrm{~Bq} \mathrm{~L}^{-1}$ of its decay product $\left({ }^{210} \mathrm{~Pb}\right)$ was much higher than the WHO guidance level of $0.1 \mathrm{~Bq} \mathrm{~L}{ }^{-1}$. The ${ }^{226} \mathrm{Ra}$ and ${ }^{228} \mathrm{Ra}$ concentrations were 0.65 and $0.38 \mathrm{~Bq} \mathrm{~L}^{-1}$ relative to the WHO guidance level of 1.0 and $0.1 \mathrm{~Bq} \mathrm{~L}^{-1}$, respectively. Rock samples taken during the drilling process were obtained directly from

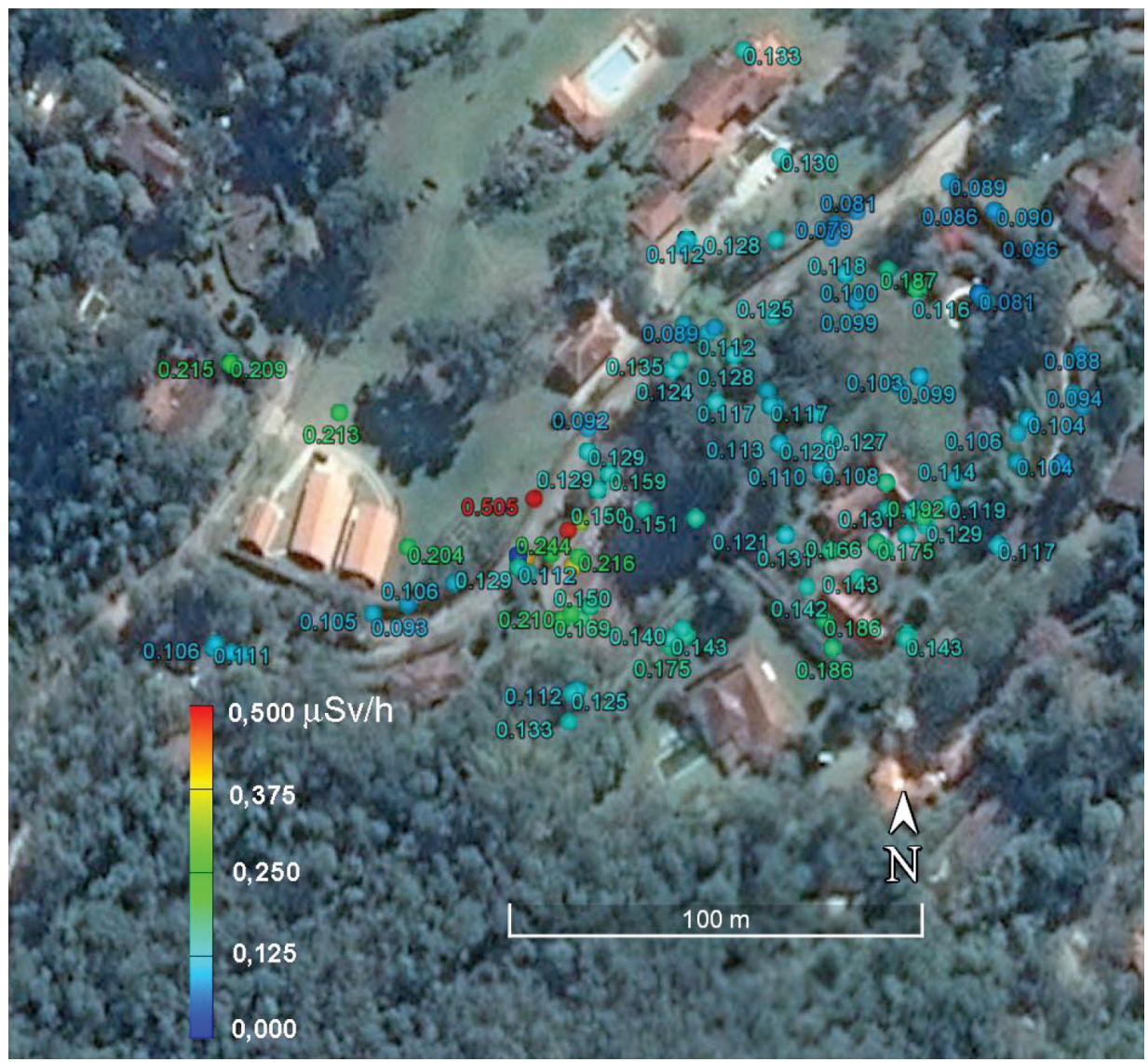

Figure 3. External gamma dose rate measured at the site 2 location with a hot spot corresponding to the wellhead. 
the drilling company, and the samples around the fracture, where the water flow occurred, were analyzed by gamma spectrometry (Figure 4). Although the ${ }^{226} \mathrm{Ra}$ concentration of $87 \mathrm{~Bq} \mathrm{~kg}^{-1}$ is far from an abnormal value for Brazilian ornamental rocks, ${ }^{21}$ a sharp increase in the ${ }^{226} \mathrm{Ra} /{ }^{228} \mathrm{Ra}$ ratio was observed in the fracture region, which agrees with the ratio observed in the water (1.7), indicating that the leached radium isotopes originate from minerals existing in the fracture.

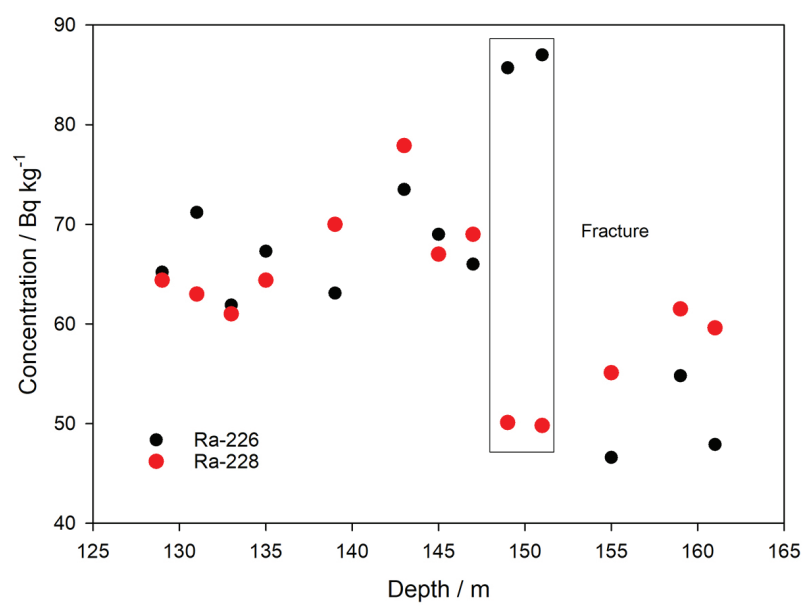

Figure 4. ${ }^{228} \mathrm{Ra}$ and ${ }^{226} \mathrm{Ra}$ profiles of rock samples corresponding to the well from site 2 .

Considering the measured ${ }^{210} \mathrm{~Pb}$ concentration and an adult water consumption of two liters daily, ${ }^{19}$ the annual dose is $2.4 \mathrm{mSv}$ year $^{-1}$; this contribution alone is more than triple the $1 \mathrm{mSv}$ year ${ }^{-1}$ mean background radiation value. After considering these findings, the well was sealed.

Sites 3 (Petrópolis County), 6 (Paraíba do Sul County) and 7 (Três Rios County) represent wells with a uranium concentration between 15 and $30 \mu \mathrm{g} \mathrm{L}^{-1}$ and were included to better define the sub-region where an elevated uranium concentration was observed.

Site 4 was a horse farm in Teresópolis County, only $14 \mathrm{~km}$ south of site 8, with an artesian well $85 \mathrm{~m}$ deep that presented a uranium concentration of $270 \mu \mathrm{g} \mathrm{L}^{-1}$, nine times above the current limit. Site 5 represented two wells drilled at a small mall in Sapucaia County, $17 \mathrm{~km}$ north of site 8 , and the observed uranium concentrations were 52 and $390 \mu \mathrm{g} \mathrm{L} \mathrm{L}^{-1}$.

During the last year, some commercial chemical analysis laboratories in Rio de Janeiro have implemented ICP-MS for the determination of metals, including uranium. Site 8 emerged when a county administration sent a sample from one of its seventeen wells to one of these laboratories. Uranium and manganese levels exceeding the Brazilian regulatory limits were observed, and the incident was reported by the press. ${ }^{22}$ In fact, the situation in this county,
São José do Vale do Rio Preto, is quite dramatic, because its water supply is entirely based on groundwater and each well supplies a neighborhood; consequently, when a well is closed, the closure results in many houses without water. From each well, the water is pumped to a water tank and directly distributed to the network without any treatment, except eventual chlorination. From the seventeen groundwater wells, which belong to the city water supply network, analyzed during the present work, seven wells presented uranium concentrations higher than $30 \mu \mathrm{g} \mathrm{L}{ }^{-1}$, with a maximum value of $185 \mu \mathrm{g} \mathrm{L}^{-1}$. These results indicate that $40 \%$ of the São José do Vale do Rio Preto water supply was not potable.

Table 3 shows the results obtained for uranium, ${ }^{222} \mathrm{Rn}$, ${ }^{226} \mathrm{Ra}$ and ${ }^{210} \mathrm{~Pb}$ in the São José do Vale do Rio Preto (SJVRP) groundwater samples. Perhaps due to the sampling conditions, there was no correlation observed between ${ }^{222} \mathrm{Rn}$ and ${ }^{210} \mathrm{~Pb}$. Nevertheless, the well with the highest ${ }^{222} \mathrm{Rn}$ concentration also had the highest ${ }^{210} \mathrm{~Pb}$ concentration. There is no Brazilian regulatory limit for ${ }^{222} \mathrm{Rn}$ in water; therefore, the United States Environmental Protection Agency's (US-EPA) alternative maximum contaminant level (MCL) of $148 \mathrm{~Bq} \mathrm{~L}^{-1}$ was applied as a reference, ${ }^{23}$ and eight of the nine ${ }^{222} \mathrm{Rn}$ values were above this MCL. Additionally, considering the WHO guidance level of $0.1 \mathrm{~Bq} \mathrm{~L}^{-1}$ for ${ }^{210} \mathrm{~Pb},{ }^{7} 100 \%$ of the wells exceeded this level. The ${ }^{226} \mathrm{Ra}$ concentrations were lower than the ${ }^{210} \mathrm{~Pb}$ values, except for sample SJVRP-1, and also bellow the maximum allowed concentration existing in the Brazilian regulation, ${ }^{7}$ and the ${ }^{228} \mathrm{Ra}$ concentrations were below the detection limit $\left(0.050 \mathrm{~Bq} \mathrm{~L}^{-1}\right)$ in all SJVRP samples.

The hydrochemical facies of these 17 wells were quite similar, representing calcium bicarbonate waters, as observed for the site 1 samples. The Durov diagram shows that the main differences, in this case, were $\mathrm{pH}$ and total dissolved solids (Figure 5); however, there was no correlation between uranium and conductivity (determination coefficient $\left(\mathrm{R}^{2}\right)=0.315$ ).

Considering all the samples with a uranium concentration greater than $30 \mu \mathrm{g} \mathrm{L}^{-1}$, regardless of their origin, it was not possible to establish any statistically valid correlation between the uranium and other chemical or physicalchemical parameters. The highest correlation observed was between the conductivity and total hardness values, reflecting the hydrochemical facies of the groundwater from this region, which is derived from the carbonate intrusions. ${ }^{6}$ Although they did not have a statistically valid correlation with the uranium levels, an elevated fluoride concentration was commonly observed during this study, which may suggest that fluorapatite is a potential uranium source in this region. ${ }^{24}$ In addition, the ${ }^{226} \mathrm{Ra}$ concentration 


\section{Durov Diagram}

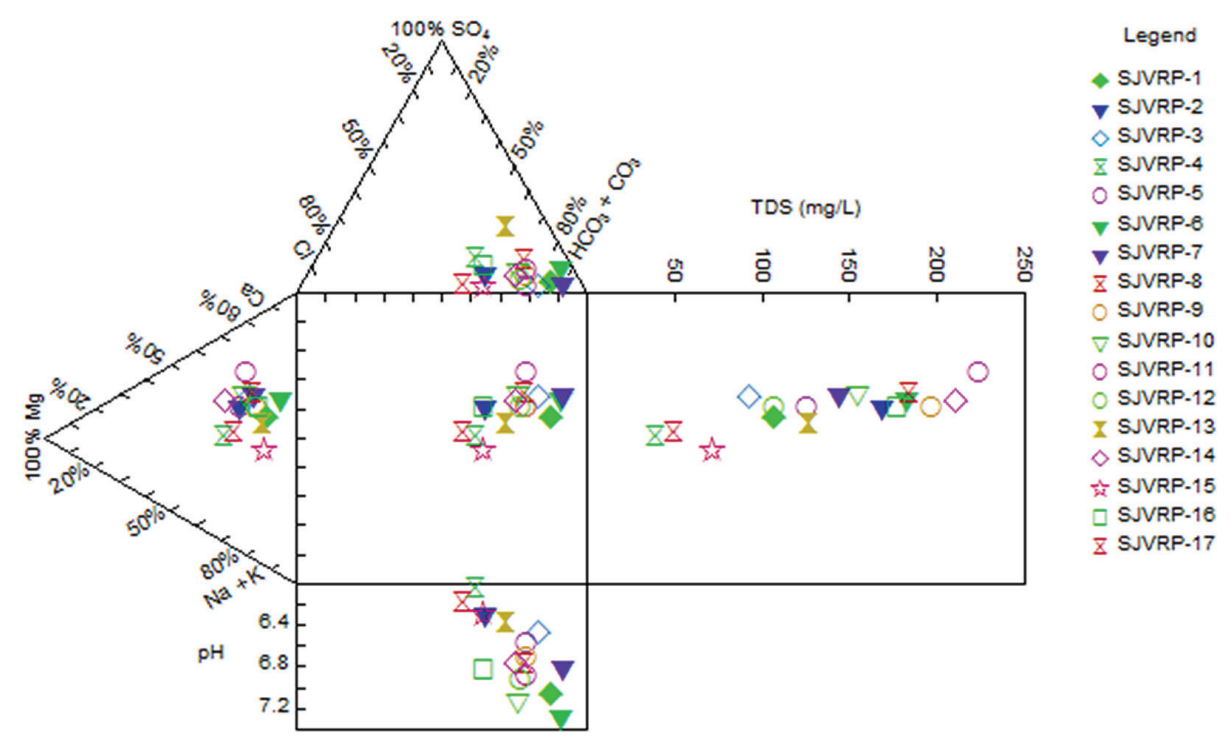

Figure 5. Durov diagram of the samples from site 8.

was higher than the ${ }^{228} \mathrm{Ra}$ concentration, which is not the case for Brazilian magmatic rocks; ${ }^{21}$ thus, the Ra ratio may also support the fluorapatite hypothesis.

The suggestion by Yang et al. ${ }^{4}$ to test for uranium in all wells within a distance of 5-10 km from a mapped granitic boundary implies that any well in this mountainous region near Rio de Janeiro City should be tested for uranium.

In the 16 counties in the mountainous region near Rio de Janeiro, uranium concentrations exceeding the regulatory limit were observed in five counties. Figure 6 highlights the sub-region where uranium concentrations above the Brazilian regulatory limit for public water supply ${ }^{7}$ have been observed. The yellow dots represent the locations with values between 15 and $30 \mu \mathrm{g} \mathrm{L}{ }^{-1}$, the two Brazilian regulatory limits, and the red dots represent wells with concentrations higher than $30 \mu \mathrm{g} \mathrm{L}{ }^{-1}$, the regulatory limit for public water supply systems. Another parameter that could be applied is the well depth, as high uranium contamination was observed only in wells deeper than $80 \mathrm{~m}$.

It was looked for additional artesian wells within this sub-region in order to validate this hypothesis. However, despite the existence of several registered wells, it was not possible to access them even with the help of the local authorities. Therefore, it was decided to try another approach. There is a large brewery, approximately $7 \mathrm{~km}$ from SJVRP, which, according to the Rio de Janeiro State environmental authority (INEA), has 17 registered artesian wells, with depths ranging from 64 to $300 \mathrm{~m}$. Because one of the main ingredients in beer is water, it is reasonable to assume that the water applied is a blend of these wells, mixed according to their chemical composition to maintain consistency, and therefore, the uranium concentration in the beer should reflect this mixture and should also be reasonably constant, independent of when it was produced. If at least one of these wells contains an elevated uranium concentration, the uranium concentration in beer produced at this plant should be higher from those produced in the "Região Serrana", but outside this sub-region.

Fourteen beer samples were analyzed and the obtained results are shown in Table 4; samples 1-6 were bought at the brewery shop, and samples 7-14 were produced in other breweries from the region, but outside from this subregion. As supposed, the uranium concentration in the beer produced in this facility, near SJVRP, is nearly constant and independent of the fabrication period, with a mean value of $1.77 \mu \mathrm{g} \mathrm{L}^{-1}$ and a relative standard deviation of $20 \%$. Because the brewing process involving these six brands are quite different, it is possible to conclude that uranium is present as a stable complex and is not removed from the solution by the beer yeast. ${ }^{25}$ When compared with the brands produced by other facilities in the same region, but outside this sub-region, the uranium concentration is clearly higher than the others, and it seems valid the hypothesis that at least one of their 17 artesian wells contain an elevated uranium concentration.

Only two references related to the uranium concentration in beer were found in the literature, ${ }^{26,27}$ and both references presented quite similar values of 0.4 and $0.3 \mu \mathrm{g} \mathrm{L}^{-1}$, respectively, showing that a beer product with a uranium content of $1.77 \mu \mathrm{g} \mathrm{L}^{-1}$ is not quite usual. However, it must be pointed out that these values are much lower than the $30 \mu \mathrm{g} \mathrm{L} \mathrm{L}^{-1}$ guidance level for drinking water. 

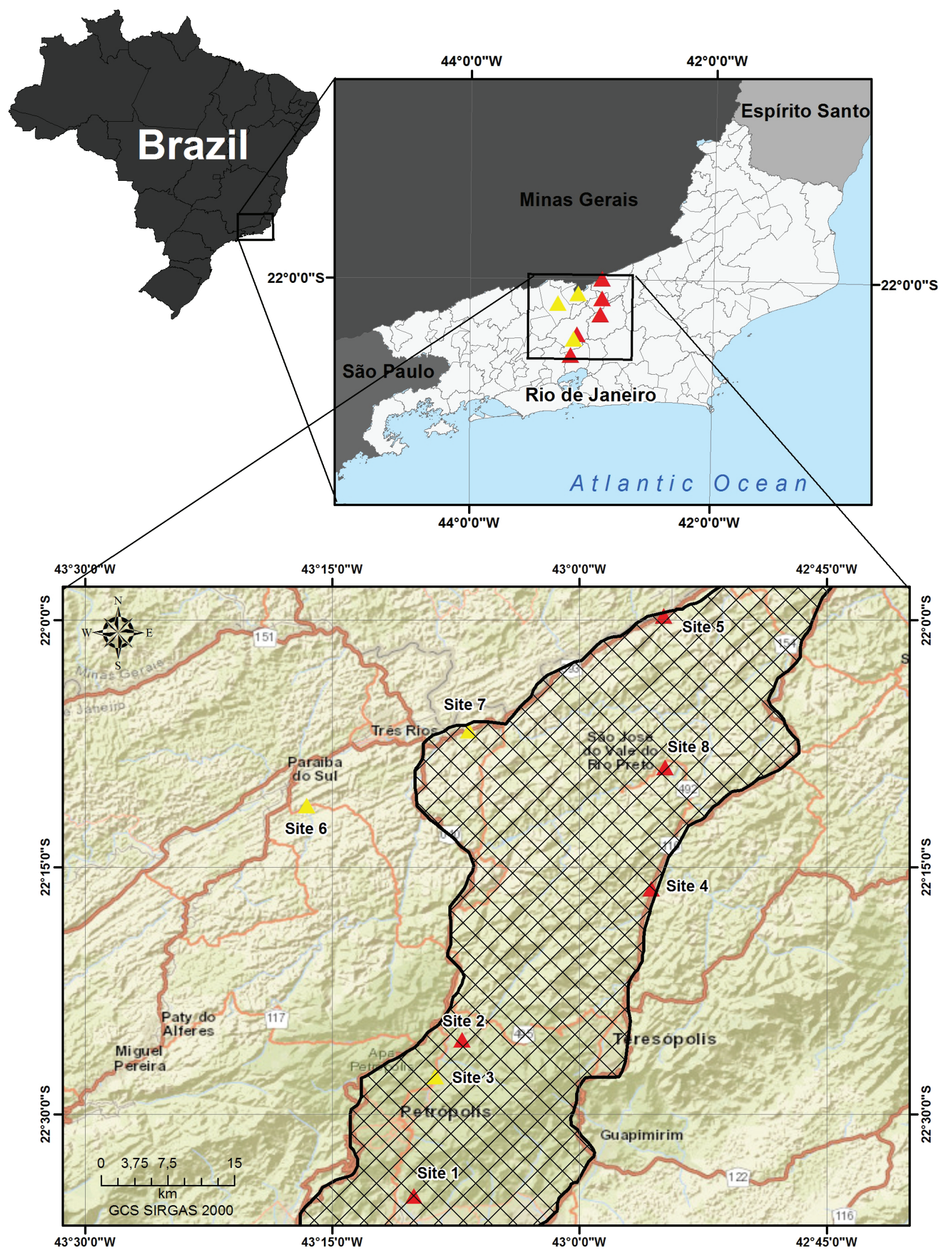

Figure 6. Occurrences of high uranium concentrations in groundwater in the mountainous region around Rio de Janeiro City (red triangles indicate uranium concentrations higher than $30 \mu \mathrm{g} \mathrm{L}^{-1}$ and yellow triangles indicate uranium concentrations between 15 and $30 \mu \mathrm{L} \mathrm{L}^{-1}$ ). 
Table 4. Uranium content in beer brands produced in the Rio de Janeiro mountainous region (samples 1-6 were produced at the facility near São José do Vale do Rio Preto)

\begin{tabular}{lcc}
\hline Sample & Fabrication date & Uranium / $\left.(\mu \mathrm{g} \mathrm{L})^{-1}\right)$ \\
\hline 1 & April 2018 & 2.23 \\
2 & April 2018 & 1.34 \\
3 & January 2018 & 2.15 \\
4 & January 2018 & 1.45 \\
5 & January 2018 & 1.69 \\
6 & February 2016 & 1.75 \\
7 & April 2018 & 0.57 \\
8 & April 2018 & $<0.020$ \\
9 & April 2018 & $<0.020$ \\
10 & April 2018 & $<0.020$ \\
11 & April 2018 & $<0.020$ \\
12 & February 2016 & 0.50 \\
13 & February 2016 & 0.25 \\
14 & February 2016 & 0.029 \\
\hline
\end{tabular}

\section{Conclusions}

Elevated uranium concentrations in groundwater, up to $930 \mu \mathrm{g} \mathrm{L}^{-1}$, were observed in seven of the sixteen counties belonging to the so-called Rio de Janeiro State "Região Serrana", the mountainous region near Rio de Janeiro City. These results have strong social consequences because elevated uranium concentration impacts the public water supply and the tourism industry. Wells with elevated uranium concentrations also present high radon contents, and consequently, ${ }^{210} \mathrm{~Pb}$ concentrations above the WHO guidance level of $0.1 \mathrm{~Bq} \mathrm{~L}^{-1}$. Because the drilling of deep artesian wells is a growing trend in this region, it is highly recommended to establish mandatory uranium and ${ }^{222} \mathrm{Rn}$ testing on any new well deeper than $80 \mathrm{~m}$ and to conduct a survey on the existing wells. It was also possible to define a sub-region where it is higher the probability of occurrence of uranium concentration, in artesian wells, above the Brazilian regulatory limit.

\section{Acknowledgments}

The present work was partially supported by Fundação Carlos Chagas Filho de Amparo à Pesquisa do Estado do Rio de Janeiro (FAPERJ) and Conselho Nacional de Desenvolvimento Científico e Tecnológico (CNPq).

\section{References}

1. Godoy, J. M.; Godoy, M. L. D. P.; J. Environ. Radioact. 2006, 85,71 .

2. Banks, D.; Birke, M.; Flem, B.; Reimann, C.; Appl. Geochem. 2015, 59, 200.
3. Dinelli, E.; Lima, A.; Albanese, S.; Birke, M.; Cicchella, D.; Giaccio, L.; Valera, P.; de Vivo, B.; J. Geochem. Explor. 2012, 112,368 .

4. Yang, Q.; Smitherman, P.; Hess, C. T.; Culbertson, C. W.; Marvinney, R. G.; Smith, A. E.; Zheng, Y.; Environ. Sci. Technol. 2014, 48, 4298.

5. Defesa Civil, Prefeitura Municipal de Petrópolis, Plano de Contigência, Plancon, Estiagem 2017, versão 01 de 20/05/2017, available at http://www.petropolis.rj.gov.br/ pmp/phocadownload/programas_governo/plano_inverno/ plancon\%20estiagem\%202017\%20-\%20versao\%2001.pdf, accessed in February 2018.

6. Martins, A. M.; Mansur, K. L.; Erthal, F. L. C.; Maurício, R. C.; Pereira Filho, J. C.; Caetano, L. C.; Águas Minerais do Estado do Rio de Janeiro; Departamento de Recursos Minerais do Estado do Rio de Janeiro: Rio de Janeiro, Brazil, 2002.

7. Ministério de Estado da Saúde, Portaria No. 2914, Procedimentos de Controle e de Vigilância da Qualidade da Água para Consumo Humano e Seu Padrão de Potabilidade, de 12 de Dezembro de 2011, Brazil.

8. Eaton, A. D.; Clesceri, L. S.; Rice, E. W.; Greenberg, A. E.; Standard Methods for the Examination of Water and Wastewater, 7500-Rn B Liquid Scintillation Method, $21^{\text {st }}$ ed.; American Public Health Association: Washington, USA, 2005.

9. Godoy, J. M.; Amaral, E. C. S.; Godoy, M. L. D. P.; J. Environ. Radioact. 2001, 53, 175.

10. Associação Brasileira de Normas Técnicas (ABNT), NBR-13798-97: Água, Determinação da Cor, Método da Comparação Visual; ABNT: Rio de Janeiro, 1997.

11. Associação Brasileira de Normas Técnicas (ABNT), NBR11265-90: Águas Minerais e de Mesa - Determinação de Turbidez; ABNT: Rio de Janeiro, 1990.

12. ASTM D1293-18: Standard Test Methods for pH of Water; ASTM International: West Conshohocken, PA, 2018.

13. ASTM D1125-14: Standard Test Methods for Electrical Conductivity and Resistivity of Water; ASTM International: West Conshohocken, PA, 2014.

14. ASTM D1067-16: Standard Test Methods for Acidity or Alkalinity of Water; ASTM International: West Conshohocken, PA, 2016.

15. ASTM D4327-17: Standard Test Method for Anions in Water by Suppressed Ion Chromatography; ASTM International: West Conshohocken, PA, 2017.

16. ASTM D6919-17: Standard Test Method for Determination of Dissolved Alkali and Alkaline Earth Cations and Ammonium in Water and Wastewater by Ion Chromatography, ASTM International: West Conshohocken, PA, 2017.

17. United States Environmental Protection Agency (US EPA), Method 200.8: Determination of Trace Elements in Waters and Wastes by Inductively Coupled Plasma - Mass Spectrometry; Revision 5.4; US EPA: Cincinnati, OH, USA, 1994. 
18. Cressweel, A. J.; Sanderson, D. C. W.; Harrold, M.; Kirley, B.; Mitchell, C.; Weir, A.; J. Environ. Radioact. 2013, 124, 22.

19. World Health Organization (WHO); Guidelines for DrinkingWater Quality, $4^{\text {th }}$ Edition Incorporating the First Addendum; available at http://www.who.int/water_sanitation_health/waterquality/guidelines/en/, accessed in February 2018.

20. Magalhães, M. H.; Amaral, E. C. S.; Sachet, I.; Rochedo, E. R. R.; J. Environ. Radioact. 2003, 67, 131.

21. Leal, A. L. C.; Lauria, D. C.; J. Radiol. Prot. 2016, 36, 680.

22. https://g1.globo.com/rj/regiao-serrana/noticia/laudo-apontauranio-e-manganes-acima-do-limite-permitido-em-agua-depoco-na-serra-do-rj.ghtml, accessed in August 2018.
23. Cothern, C. R.; Rebers, P. A.; Radon, Radium and Uranium in Drinking Water; Lewis Publishers: Michigan, USA, 1990.

24. Banning, A.; Rüde, T. R.; Appl. Geochem. 2015, 59, 139.

25. Popa, K.; Cecal, A.; Drochioiu, G.; Pui, A.; Humelnicu, D.; Nukleonica 2003, 48, 121.

26. Skwarzec, B.; Stuminska, D. I.; Borylo, A.; Falandysz, J.; J. Radioanal. Nucl. Chem. 2004, 261, 661.

27. Anke, M.; Seeber, O.; Müller, U.; Schäfer, U.; Zerull, J.; Chem. Erde 2009, 69, 75.
Submitted: May 25, 2018

Published online: September 3, 2018 